\title{
The Effect of Managerial Ability on Financial Reporting Quality: An Empirical Analysis of the Banking Industry
}

\author{
Sinta Juliani ${ }^{1}$ and Sylvia Veronica Siregar ${ }^{2}$ \\ ${ }^{1,2}$ Accounting Department, Faculty of Economy and Business University Indonesia, Indonesia \\ ${ }^{1}$ sinta.juliani30@gmail.com, ${ }^{2}$ sylvia.veronica@ui.ac.id
}

\begin{abstract}
This study aims to examine the effect of managerial ability on financial reporting quality. The samples of this study are listed banks in the Indonesia Stock Exchange during the period of 2010 to 2016. with total observations are 210 firmyears. Managerial ability is measured using Data Envelopment Analysis (DEA). Earnings persistence and earnings predictability are used to measure financial reporting quality. By using panel data regression, the results show that managerial ability has a negative effect on financial reporting quality, for both measures. This may be due to when the manager has higher ability, he/she tends to be opportunistic and take actions (such as opportunistic earnings management) and thus earnings become less persistent as well as less predictable (low financial reporting quality).
\end{abstract}

Keywords: Banking, Financial Reporting Quality, Managerial Ability.

\section{Introduction}

Financial statements issued by companies are the results of accounting process and contains many useful financial information about firm performance. especially to external parties. Management is the party with the responsibility for the managing company operations. They also responsible for the preparation of financial statements, so that their ability or skill will affect the quality of the report. Financial statements should be able to provide information about management performance in running the business.

Management as insider always have information advantage over external parties. The presence of this information asymmetry provides opportunity for management to take opportunistic actions to conceal its bad performance by doing earnings management. Managers are the main actors in the companies, and so with better managerial ability it is expected the companies' performance will also be better. Managerial ability should also play an important role in determining financial reporting quality because managers with high managerial ability would have better knowledge of their business and be able to make effective judgments and take appropriate actions, so that it could utilize company resources effectively and ultimately could achieve better company performance (Wang et al., 2017). Managers' ability could also influence financial reporting quality with their attitudes toward internal control and through their role as information channels to directors. other managers. and auditors [1] In other words, managerial ability can affect financial reporting quality.

Garcia-Meca \& Garcia-Sanchez [2] examine the effect of managerial ability on financial reporting quality. They find that higher managerial ability able to produce higher bank earnings 
quality. which means that managerial ability plays an important role in shaping the financial reporting quality in banks. We extend their research by doing similar study in Indonesia. To the best of our knowledge. there have not been any studies examining the effect of managerial ability on financial reporting quality in the banking sector in Indonesia. Managerial ability is very relevant in the bank industry because of the information asymmetry. opacity and greater complexity in this sector [3]. Banking companies in Indonesia have grown rapidly which are stimulated by the development of information technology. Information technology-based banking innovation has an extraordinary impact on efficiency and effectiveness. Thus. managerial ability is expected to play more significant role in banking industry.

\section{Literature Review and Hypotheses Development}

According to Jensen and Meckling[4]agency relationship was a contract between manager (agent) and principal, in which there was an authority delegation in decision-making from the principal to the manager. The principal delegate the authority on decision-making to agent (manager) and expects that the manager will take certain actions that are in line with the interests of the principal.

Based on Arkerlof[5]. agency theory was characterized by information asymmetry. which are moral hazard and adverse selection. Bouckova[6] suggests that information asymmetry could lead to moral hazard, in which one party with information advantage (i.e. management) exploited the information asymmetry for their own personal benefit. The principal has limitations in controlling agent behavior and can only evaluate manager performance based on reported results in financial report which are prepared by the management.

One theory that emphasizes the important role of managers is resource-based view theory Holcomb[7].According to this theory, the ability of managers to utilize existing resources is a valuable resource to enhance the company's competitive advantage. The manager's ability is influenced by the accumulation of knowledge gained through education or work experience, which influences his/her ability to make decisions. Another related theory is upper echelons theory which states that the characteristics of each manager influence the ability of managers to analyze the situation so that it will affect the company's performance[8]

Demerjian [9] develop a measure of managerial ability by estimating how efficiently managers use company resources compared to companies in their industries. Further, Demerjian[10]stated that managers with higher ability have more knowledge about business conditions, have more persistent profits, and are more accurate in estimating accruals. They find that companies with high management skills had better quality financial reporting.

Garcia-Meca and Garcia-Sanchez[2] measured financial reporting quality by using three measurements, namely earnings persistence, predictability, and accounting conservatism. The measurements are in line with the earnings attributes[11] by Francis.Earnings persistence represents expected accounting earnings in the future which is reflected in current year earnings. Persistence is one measure of financial reporting quality, where higher persistence indicate a sustainable profit[12]. Earnings persistence is an attribute of earnings quality which shows the company's ability to maintain the current earnings to persist in the future. High earnings persistence is more useful in the decision making process[13]. Another measurement of financial reporting quality is predictability. Predictability is how the current profitability able to predict future operating cash flows[14] .Earnings are said to be unpredictable when earnings is volatile and unpredictable[15] (Graham et al., 2005). Increase earnings predictability can provide useful information as current year earnings can be informative in predicting future earnings. 
Managers are important players in companies. so with better managerial capability, it is expected that the companies' performance will be higher. The resource-based view theory argues that the ability of managers to effectively use the company resources are valuable and potential resources to produce certain conservative characteristics that affected reporting quality[16] .The more specific the managers' capabilities which were embedded within them, the more possibilities that they could not be transferred to other companies and they were very difficult to be imitated by competitors. so that this made them a significant sources of highperformance companies[17].

There are several extant studies examining the effect of of managerial ability on financial reporting quality. Wang et al. (2017) argued that more capable managers would have knowledge of their business and could make effective judgments and forecasts so as that they could alter companies' resources better and ultimately they could achieve better business performance. In addition. managers could also affect financial reporting quality with their attitudes toward internal controls and through their role as information channels to directors, other managers, and auditors[1]. Garcia-Meca and Garcia-Sanchez [2] find that managerial ability have significant positive effect on financial reporting quality. Based on the explanations above, the hypothesis is as follows.

H1: There is a positive effect of managerial ability on financial reporting quality.

\section{Research Method}

The population in this study are listed banks on Indonesia Stock Exchange (IDX) in the period 2010-2016. The sample selection criteria are: (1) bank listed on IDX during 2010-2016; (2) Published financial statements during 2010-2016. The selection of banking sector because banking companies have asymmetric information. opacity. and greater complexity compared to other sectors. so that this selection makes more relevant to research on managerial capability and quality of financial reporting. Based on those sample selection criteria. we have 30 banking companies in each year. with a total of 210 observations.

In this study. the dependent variable is financial reporting quality. Financial reporting quality is closely related to the performance of the company embodied in the company's earnings. Higher earnings quality provides more information about the company's financial performance that is relevant to the decision made by the decision maker. Referring to Garcia-Meca \& GarciaSanchez[2] .this study measures the quality of earnings by using earnings persistence and predictability.

Earnings persistence is an attribute of earnings that demonstrates a company's ability to retain the amount of profit gained now to the future. Profit persistence can be the basis in the assessment of earnings quality. because high quality profits are more persistent and useful in the decision making process. The model used to measure the profit persistence is as follows.

$$
\begin{aligned}
\text { EBT }_{i t+1}=\varpi_{0}+ & \varpi_{1} \text { EBT }_{i t}+\varpi_{2} M A_{i t}+\varpi_{3} \text { MA }_{i t} * \mathrm{EBT}_{i t}+\varpi_{4} \text { SIZE }_{i t} \\
& +\varpi_{5} \text { SIZE }_{i t} * \mathrm{EBT}_{i t}+\varpi_{6} \text { DEPOSITS }_{i t}+\varpi_{7} \text { DEPOSITS }_{i t} \\
& * \mathrm{EBT}_{i t}+\varpi_{8} \text { LOANGROWTH }_{i t}+\varpi_{9} \text { LOANGROWTH }_{i t} * \mathrm{EBT}_{i t} \\
& + \text { YEAR }_{i t}+\varepsilon_{i t}
\end{aligned}
$$

Where:

$\mathrm{EBT}_{\text {it }+1}=\quad$ earnings before tax scaled by total assets at the beginning of year $\mathrm{t}$

$\mathrm{MA}_{\mathrm{it}}=\quad$ managerial ability

$\mathrm{SIZE}_{\mathrm{it}}=\quad$ company size (natural logarithm of total assets)

DEPOSIT $_{i t}=\quad$ the amount of deposit scaled by total assets at the beginning of year $\mathrm{t}$

LOANGROWTH $_{\mathrm{it}}=$ the difference between bank credit growth rate and the median of credit growth of all listed banks 
In this study. the measurement used for earnings persistence is by looking at the coefficient of current period earnings (EBTt) or $\varpi_{1}$. Higher coefficient means higer aernijgs persistence (higher financia reporting quality). Whereas $\varpi_{3}$ shows the effect of managerial ability on earnings persistence.

Predictability is also a measurement of financial reporting quality. Predictability is the ability of current profitability to predict future cash flow. This is often used as one measurement of financial reporting quality since investors consider that cash flow as more relevant than profitability. and more useful in the predictability for liquidity and solvency (Garcia-Meca \& Garcia-Sanchez, 2017).

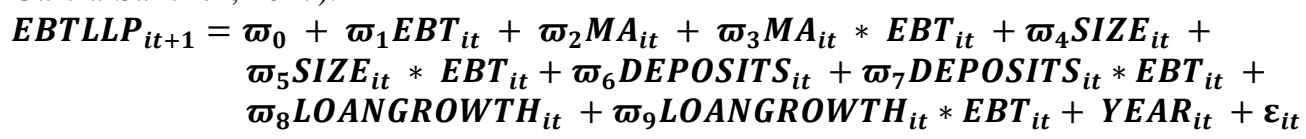

Where:

EBTLLP $_{\text {it }+1}$ is $\mathrm{EBT}_{\mathrm{it}+1}$ plus loan loss provision year $\mathrm{t}+1$. scaled by total asset at the beginning of year $\mathrm{t}$

To measure the ability of earning ability in predicting future cash flows or predictability. earnings regression and loan loss provisions are used one period ahead of current period earnings. Previous research in banking had done by using pre-tax profit and loan loss provision as a measure of predictability. since loan loss provision was the largest accrual on the bank[18]. Thus. variable of EBTLLPt +1 is used which is the amount of profit and loan loss provision one period ahead.

Managerial ability is measured using DEA (Data Envelopment Analysis). DEA is a method used to evaluate the efficiency of a responsible decision-making unit by using a number of inputs to obtain a targeted output. DEA is used to determine the firm's optimal weight on its inputs and outputs. The optimal weight of the company will describe the efficiency of the company. To measure managerial ability. this study used two-stage DEA. DEA approach used is Variable Returns to Scales (VRS). To calculate DEA. DEAP application is used. To measure efficiency with the DEA approach. the model is as follows:

$\operatorname{Max} \theta=\frac{u 1 \text { Deposits }+u 2 \text { Loans }+u 3 \text { Investment }+u 4 \text { IntInco }}{v 1 P P E+v 2 \text { Int }+v 3 \text { Labor }+v 4 \text { IntExp }+v 5 \text { RentExp }}$

Where:

$\theta \quad=$ Firm efficiency

Deposits $\quad=$ Total deposit

Loans $\quad=$ Loan or credit

Investment $=$ Investment

IntInco = Interest income

PPE $\quad=$ Net properties. plant. \& equipment

Int $\quad=$ Intangible assets

Labor $\quad=$ Labor costs

IntExp = Interest charges

RentExp $\quad=$ Rental expenses 
The results of this efficiency captures both firm efficiency and management efficiency. To separate the firm's effect from managerial ability. Following Garcia-Meca \& Garcia-Sanchez (2017), we estimate following regression equation:

DEAScore $=\beta_{0}+\beta_{1}$ Size $+\beta_{2}$ Market_Share $+\beta_{3}$ Cash_Flow $+\beta_{4}$ Age + Year $+\varepsilon$

Where:

DEAScore

Size

Market_Share

$=$ Company efficiency

$=$ Company size (natural logarithm of total assets)

all banking companies)

Cash_Flow $\quad=\quad$ Free Cash Flow, 1 if company has positive free cash flow and 0 if

otherwise

Age $\quad=\quad$ Number of years listed on the stock exchange

$\varepsilon$

$=$ Residual value

The residual value of the above regression reflects the efficiency level of the management and is used to measure managerial ability (MA).

Table 1: Sample Selection

\begin{tabular}{ll}
\hline Criteria & Samples \\
\hline Listed banks on 31 December 2016 & 45 \\
Banks listed after year 2010 & $(15)$ \\
Sample listed banks & 30 \\
Number of observations 2010-2016 & 210 rm years \\
\hline
\end{tabular}

\section{Results and Discussion}

Table 2 shows descriptive statistics of the variables. Based on table 1. the value of EBT. EBT1. and EBTLLP1 on average have a positive value. This indicates that the most of the sample companies have a positive profitability. Variable MA (managerial ability) has mean -0.0354 . In average. thus. managerial ability in our samples are quite low. A lack of managerial ability may indicate that the company's managers have not been able to efficiently manage the company's resources or they do not have sufficient expertise. We use random effect (RE) approach and Generalized Least Square (GLS) technique to run our regressions. Random effect (RE) assumes that error has inter-time and cross-section relationships. Table 3 and Table 4 present the regression results.

Based on the results of the regression in Table 2, coefficient of MA*EBT is negative and significant at $1 \%$. It means that managerial ability has negative influence on earnings persistence (and financial reporting quality). Higher managerial ability result in lower earnings persistence. Thus. H1 is not supported. This result is inconsistent with Garcia-Meca and Garcia-Sanchez [2] which find that managerial ability has positive and significant effect on earnings persistence. However, our result is consistent with Francis[19] and [20]. According to Francis[19] the higher the managerial ability, the manager will tend to take risks and choose challenging projects for the company. Therefore, although they have high managerial ability, it is uncertain that they can reduce uncertainty about earnings persistence as they tend to be risk seeker. Hassanzadeh [20] find that managerial ability has a significant negative effect on earnings persistence. They argue 
that the manager with high managerial ability tend to report losses on financial reports due to the opportunistic nature of managers to reduce company taxes. Manager's opportunistic behavior is closely related to earnings management. Adiati [21] suggests that companies that do earnings management have lower earnings persistence than other companies.

SIZE has a significant negative effect on earnings persistence. which means the larger the company the lower the earnings persistence (financial reporting quality). This result is inconsistent with Setyawati[22]which suggest that the larger company has higher financial reporting quality. DEPOSITS has a positive significant influence on earnings persistence. Thus, higher third party funds has a significant positive effect on financial reporting quality. This result is consistent with our expectation. The other control variable (LOANGROWTH) has insignificant effect on earnings persistence.

Regression result on predictability also show managerial ability has negative association with predictability, consistent with earnings persistence result. Again, the result indicates that higher managerial ability result in lower financial reporting quality. Due to mean managerial ability shows negative amount, which means that in average managerial ability in our samples is quite low, it is possible that the negative association is drive by low managerial ability firms. To examine this possibility, we divide our samples into sub sample of low managerial ability and high managerial ability (based on median of managerial ability). The results are presented in Table 5 for earnings persistence and Table 6 for earnings predictability.

From both tables we can see that in low managerial sub sample, we observe consistent results with the main results, which are negative effect of managerial ability on financial reporting quality. Whereas for high managerial ability sub samples, the results show insignificant effect of managerial ability on financial reporting quality.

Table 2: Descriptive Statistics

\begin{tabular}{lllll}
\hline \multirow{2}{*}{ Variable } & Mean & Std. & Min. & Max. \\
& & Dev & & \\
\hline EBT1 & 0.0190 & 0.0270 & -0.1204 & 0.0801 \\
EBTLLP & 0.0289 & 0.0255 & -0.1417 & 0.1542 \\
NIT & 0.0076 & 0.0939 & -0.0841 & 1.3510 \\
EBT & 3.30 & 6.88 & -8.60 & 34.00 \\
MA & -0.0354 & 0.0702 & -0.2721 & 0.0868 \\
SIZE & 31.2891 & 1.6512 & 28.0767 & 34.5768 \\
DEPOSIT & 96 & 151 & 1 & 740 \\
LOANGR & 1.1803 & 0.6425 & 0.0010 & 9.0907 \\
OWTH & & & & \\
DANI & 0.2285 & 0.4209 & 0 & 1 \\
NITT1 & 0.0059 & 0.1000 & -0.4969 & 1.3510 \\
& & 0 & & \\
\hline
\end{tabular}


Table 3: Regression Result of Model 1 - Earnings Persistence

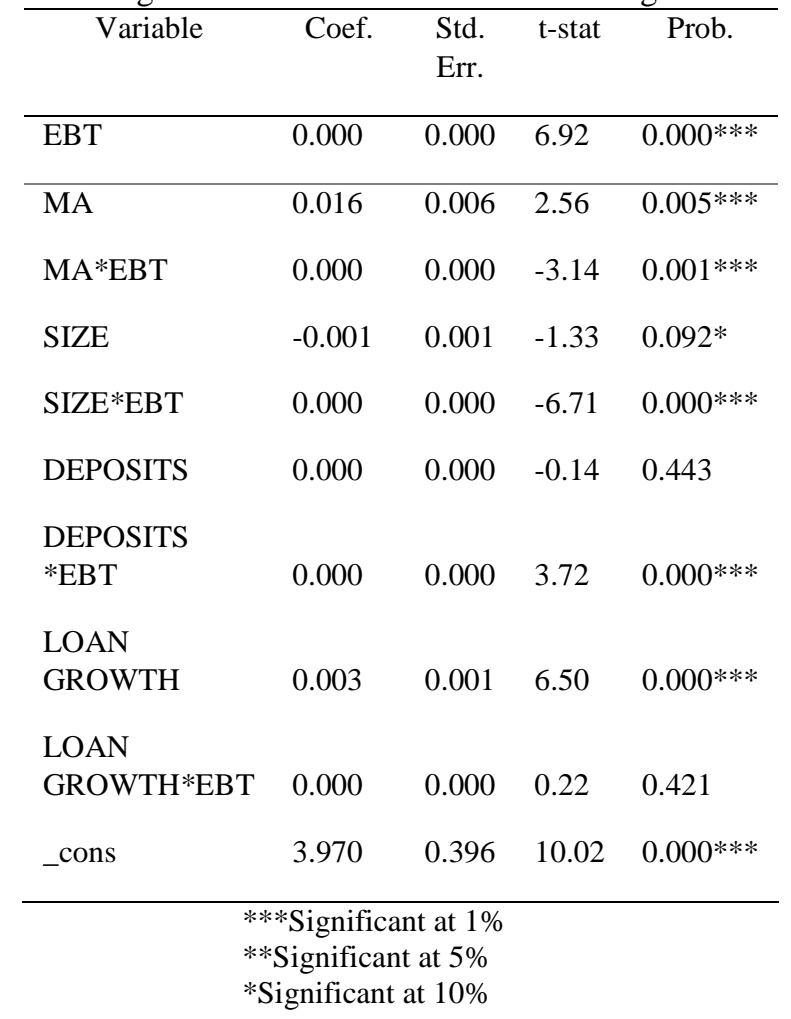

Table 4: Regression Result of Model 2 - Earnings Predictability

\begin{tabular}{lcccc}
\hline \multicolumn{1}{c}{ Variable } & Coef. & $\begin{array}{c}\text { Std. } \\
\text { Err. }\end{array}$ & t-stat & Prob. \\
\hline EBT & 0.000 & 0.000 & 5.73 & $0.000^{* * * *}$ \\
MA & 0.015 & 0.008 & 1.99 & $0.024 * *$ \\
MA*EBT & 0.000 & 0.000 & -4.08 & $0.000^{* * *}$ \\
SIZE & -0.001 & 0.001 & 1.31 & $0.095^{*}$ \\
SIZE*EBT & 0.000 & 0.000 & -5.57 & $0.000^{* * *}$ \\
DEPOSITS & 0.000 & 0.000 & -0.46 & 0.324 \\
DEPOSITS*EBT & 0.000 & 0.000 & 3.31 & $0.001 * * *$ \\
LOANGROWTH & 0.015 & 0.001 & 26.04 & $0.000^{* * *}$ \\
LOAN & & & & \\
GROWTH*EBT & 0.000 & 0.000 & -0.83 & 0.204 \\
_Cons & -0.202 & 0.029 & -0.70 & $0.482^{*}$ \\
\hline & & & &
\end{tabular}


**Significant at 5\%

*Significant at $10 \%$

Table 5: Regression Result of Sub Sample - Earnings Persistence Panel A: Low Managerial Ability

\begin{tabular}{lcccc}
\hline \multicolumn{1}{c}{ Variable } & Coef. & $\begin{array}{l}\text { Std. } \\
\text { Err. }\end{array}$ & t-stat & Prob. \\
\hline EBT & 0.000 & 0.000 & 5.06 & $0.000^{* * *}$ \\
MA & 0.017 & 0.013 & 1.37 & $0.085^{*}$ \\
MA*EBT & 0.000 & 0.000 & -1.72 & $0.043^{* *}$ \\
SIZE & -0.002 & 0.001 & -1.23 & 0.110 \\
SIZE*EBT & 0.000 & 0.000 & -4.87 & $0.000^{* * *}$ \\
DEPOSITS & 0.000 & 0.000 & 0.41 & 0.341 \\
DEPOSITS*EBT & 0.000 & 0.000 & 1.21 & 0.114 \\
LOANGROWTH & -0.008 & 0.008 & 0.97 & 0.166 \\
LOAN & & & & \\
GROWTH*EBT & 0.000 & 0.000 & 0.03 & 0.486 \\
_cons & 0.689 & 0.039 & 1.78 & $0.076^{*}$ \\
\hline
\end{tabular}

Panel B: High Managerial Ability

\begin{tabular}{|c|c|c|c|c|}
\hline Variable & Coef. & $\begin{array}{l}\text { Std. } \\
\text { Err. }\end{array}$ & t-stat & Prob. \\
\hline EBT & 0.000 & 0.000 & 2.31 & $0.011 * *$ \\
\hline MA & 0.010 & 0.069 & 0.14 & 0.444 \\
\hline MA*EBT & -0.000 & 0.000 & -0.49 & 0.311 \\
\hline SIZE & 0.001 & 0.002 & 0.20 & 0.422 \\
\hline SIZE*EBT & -0.000 & 0.000 & -2.21 & $0.014 * *$ \\
\hline DEPOSITS & -0.000 & 0.000 & -0.87 & 0.193 \\
\hline DEPOSITS*EBT & 0.000 & 0.000 & 1.30 & $0.097 *$ \\
\hline LOANGROWTH & 0.003 & 0.001 & 4.52 & $0.000 * * *$ \\
\hline $\begin{array}{l}\text { LOAN } \\
\text { GROWTH*EBT }\end{array}$ & 0.000 & 0.000 & 0.08 & 0.470 \\
\hline _cons & 0.004 & 0.071 & 0.06 & 0.955 \\
\hline & $\begin{array}{l}\text { Signifi } \\
\text { ignific } \\
\text { snifica }\end{array}$ & $\begin{array}{l}t \text { at } 1 \% \\
\text { at } 5 \% \\
10 \%\end{array}$ & & \\
\hline
\end{tabular}


Table 6: Regression Result Sub Sample - Earnings Predictability

\begin{tabular}{lcccc}
\multicolumn{5}{c}{ Panel A: Low Managerial Ability } \\
\hline \multicolumn{1}{c}{ Variable } & Coef. & $\begin{array}{l}\text { Std. } \\
\text { Err. }\end{array}$ & t-stat & Prob. \\
\hline EBT & 0.000 & 0.000 & 4.20 & $0.000^{* * *}$ \\
MA & 0.003 & 0.017 & 0.17 & 0.435 \\
MA*EBT & -0.000 & 0.000 & -1.99 & $0.024^{* * *}$ \\
SIZE & -0.000 & 0.002 & -0.23 & 0.411 \\
SIZE*EBT & -0.000 & 0.000 & -4.06 & $0.000^{* * *}$ \\
DEPOSITS & 0.000 & 0.000 & 0.91 & 0.181 \\
DEPOSITS*EBT & 0.000 & 0.000 & 0.90 & 0.184 \\
LOANGROWTH & 0.016 & 0.004 & 4.53 & $0.000^{* * *}$ \\
LOAN & & & & \\
GROWTH*EBT & -0.000 & 0.000 & -0.85 & 0.198 \\
_cons & 0.030 & 0.045 & 0.67 & 0.500 \\
\hline
\end{tabular}

Panel B: High Managerial Ability

\begin{tabular}{lcccc}
\hline \multicolumn{1}{c}{ Variable } & Coef. & $\begin{array}{c}\text { Std. } \\
\text { Err. }\end{array}$ & t-stat & Prob. \\
\hline EBT & 0.000 & 0.000 & 1.82 & $0.035^{* *}$ \\
MA & 0.103 & 0.063 & 1.63 & $0.052^{*}$ \\
MA*EBT & -0.000 & 0.000 & -0.96 & 0.170 \\
SIZE & 0.001 & 0.003 & 0.43 & 0.335 \\
SIZE*EBT & -0.000 & 0.000 & -1.70 & $0.045^{* *}$ \\
DEPOSITS & -0.000 & 0.000 & -0.96 & 0.170 \\
DEPOSITS*EBT & 0.000 & 0.000 & 0.35 & 0.362 \\
LOANGROWTH & 0.016 & 0.001 & 17.00 & $0.000^{* * *}$ \\
LOAN & & & & \\
GROWTH*EBT & 0.000 & 0.000 & 0.08 & 0.466 \\
_cons & -0.021 & 0.075 & -0.28 & 0.777 \\
\hline
\end{tabular}

***Significant at $1 \%$

**Significant at $5 \%$

*Significant at $10 \%$ 


\section{Conclusion}

This study aims to find empirical evidence about the e influence of managerial ability on financial reporting quality of listed banks in Indonesia. Based on our regression results, we find that managerial ability has a negative and significant effect on the financial reporting quality (measured by earnings persistence and earnings predictability). Higher managerial ability does not able to increase the financial reporting quality. These results are inconsistent with GarciaMeca \& Garcia-Sanchez[2] which find that managerial ability has a positive effect on the bank financial reporting quality. However, these results consistent with Francis[19] and Hassanzadeh [20]which find that managerial ability has a negative effect on financial reporting quality. This may be due to when the manager has higher ability, he/she tends to be opportunistic and take actions (such as opportunistic earnings management) and thus earnings become less persistent as well as less predictable (low financial reporting quality).

There are some limitations of our study. As we are only examining banking industry, our samples tend to limited. The results of this study also cannot be generalized to other industries. We also only use two measurements of financial reporting quality (earnings persistence and predictability). Further studies may extend the samples to non-listed banks and may use other proxies to measure financial reporting quality.

\section{References}

[1] J. K. Aier, J. Comprix, M. T. Gunlock, and D. Lee, "The Financial Expertise of CFOs and Accounting Resatements," Account. Horizons, vol. Vol.No.3, pp. 123-135, 2005.

[2] E. Garcia-Meca and I.-M. Garcia-Sanchez, "Does managerial ability influence the quality of financial reporting?,” Eur. Manag. J., pp. 1-14, 2017.

[3] R. Levine, "The Corporate Governance of Banks: A Concise Discussion of Concepts and Evidence," 2004.

[4] M. Jensen and W. Meckling, "Theory of the firm: managerial behavior, agency costs, and ownership structure," J. financ. econ., vol. 3, pp. 305-360, 1976.

[5] G. A. Arkerlof, "The Market for 'Lemons': Quality Uncertainty and the Market Mechanism,” Q. J. Econ., vol. 84, no. 3, pp. 488-500, 1970.

[6] M. Bouckova, "Management Accounting and Agency Theory," Procedia Econ. Financ., vol. 25, pp. 5-13, 2015.

[7] T. R. Holcomb, M. Holmes, and B. Connely, "Managerial ability as a source of resource value creation," Strateg. Manag. J., pp. 457-485, 2009.

[8] D. C. Hambrick, "Upper echelons Theory: An update," Acad. Manag. Rev., vol. 32, no. 2, pp. 334-343, 2007.

[9] P. Demerjian, B. Lev, and S. McVay, "Quantifying Managerial Ability: A New Measure and," Manage. Sci., vol. 58, pp. 1229-1248, 2012.

[10] P. R. Demerjian, B. Lev, M. F. Lewis, and S. E. McVay, "Managerial Ability and Earnings Quality," Account. Rev., vol. 88, pp. 2-463, 2013.

[11] J. Francis, R. LaFond, P. M. Olsson, and K. Schipper, "Costs of Equity and Earnings Attributes," Account. Rev., vol. 79, no. 4, pp. 967-1010, 2004.

[12] K. Schipper and L. Vincent, "Earnings Quality," Account. Horizons, vol. 17, pp. 97110, 2003.

[13] K. E. Abdelghany, "Measuring The Quality of Earnings," Manag. Audit. J., vol. 20, no. 8/9, pp. 1001-1015, 2005.

[14] P. M. Dechow and C. M. Schrand, "Earnings Quality," Res. Found. CFA Instiute, 2004.

[15] G. Hall, P. Hutchinson, and N. Michaelas, "Industry Effects on the Determinants of 
Unquoted SMEs’ Capital Structure,” Int. J. Econ. Bus., vol. 7, no. 3, pp. 297-312, Nov. 2000 .

[16] L. S. Bamber, J. Jiang, and I. Y. Wang, "What's My Style? The Influence of Top Managers on Voluntary Corporate Financial Disclosure," Account. Rev., vol. 85, no. 4, pp. 1131-1162, 2010.

[17] N. W. Hatch and J. H. Dyer, "Human Capital and Learning as a Source of Sustainable Competitive Advantage,” Strateg. Manag. J., vol. 25, no. 12, pp. 1155-1178, 2004.

[18] K. Kanagaretnam, "Effects of International Institutional Factors on Earnings Quality of Banks," J. Bank. Financ., pp. 87-106, 2014.

[19] J. Francis, S. Rajgopal, A. Huang, and A. Zang, "CEO Reputation and Earnings Quality," Contemp. Account., vol. 25, no. 1, pp. 109-147, 2008.

[20] R. B. Hassanzadeh, M. Khosravanian, Y. Nahandi, and M. Lalepour, "Studying the Effect of Management Ability on Profit Quality in Stock Exchange in Iran," Life Sci. J., vol. 10, pp. 76-85, 2013.

[21] A. K. Adiati, "Manajemen Laba, Large Book-Tax Differences, dan Persistensi Laba. Simposium Nasional Akuntansi," PPJK, vol. 157, 2015.

[22] L. J. Setyawati, Kualitas Informasi Pelaporan Keuangan: Faktor-Faktor Penentu dan Pengaruhnya terhadap Efisiensi Investasi. Jurnal Ekonomi, 2015. 